\title{
First record of Scobina poeciloides (Ashmead, 1895) (Hymenoptera: Argidae) for Brazil and update of geographical distribution of three species of Scobina Lepeletier \& Serville, 1828 for the State of Rio Grande do Sul
}

\author{
J. R. A. Lemes ${ }^{a *}$ and A. Köhler ${ }^{b}$ \\ a Departamento de Zoologia, Universidade Federal do Rio Grande do Sul - UFRGS, Avenida Bento Gonçalves, \\ CEP 91509-900, Porto Alegre, RS, Brazil

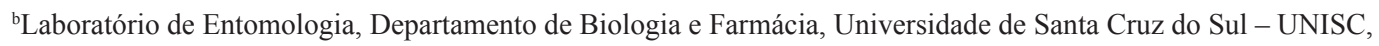 \\ Avenida Independência, 2293, CEP 96815-900, Santa Cruz do Sul, RS, Brazil \\ *e-mail: jralemes@gmail.com
}

Received: November 17, 2015 - Accepted: March 29, 2016 - Distributed: August 31, 2017

(With 5 figures)

\begin{abstract}
It is recorded for the first time in the state of Rio Grande do Sul the occurrence of Scobina melanocephala (Lepeletier, 1823), Scobina thoracica (Jorgensen, 1913) and Scobina poeciloides (Ashmead, 1895), being this last the first record for Brazil. Scobina melanopyga (Klug, 1834) and Scobina torquata (Konow, 1903) were also found in the study. The analyzed material was collected utilizing Malaise traps in tobacco (Nicotiana tabacum L.) fields and is deposited at the Entomological Collection of Santa Cruz do Sul.
\end{abstract}

Keywords: new register, sawflies, tobacco.

\section{Primeiro registro de Scobina poeciloides (Ashmead, 1895) (Hymenoptera: Argidae) para o Brasil e aumento da distribuição geográfica de três espécies de Scobina Lepeletier \& Serville, 1828 para o estado do Rio Grande do Sul}

\begin{abstract}
Resumo
É registrado pela primeira no estado do Rio Grande do Sul a ocorrência de Scobina melanocephala (Lepeletier, 1823), Scobina thoracica (Jorgensen, 1913) e Scobina poeciloides (Ashmead, 1895), esta última sendo registrada pela primeira vez no Brasil. Scobina melanopyga (Klug, 1834) e Scobina torquata (Konow, 1903) também foram encontradas no estudo. O material analisado foi coletado utilizando armadilhas de Malaise em cultivo de tabaco (Nicotiana tabacum L.) e estão depositados na Coleção Entomológica de Santa Cruz do Sul.
\end{abstract}

Palavras-chave: novos registros, mosca-serra, tabaco.

\section{Introduction}

Argidae is a cosmopolitan family comprising 51 genera and about 800 species. They are easily diagnosed and separated from other families of Hymenoptera for presenting thorax strongly linked to the abdomen, characteristic of the suborder Symphyta, and present 3-segmented antenna, with flagellum composed by a single segment (Hanson and Gauld, 1995; Fernández and Sharkey, 2006). The highest species richness is found in the Neotropics, where the family was monographed by Smith (1992), which is the only taxonomic study published for the family.

Scobina Lepeletier \& Serville, 1828 is a genus composed of about 50 species distributed from Mexico to northern Argentina. Most species of Scobina were placed in other genera by Dalla Torre (1894) and Konow (1907).
Afterwards, Malaise (1937) characterized and synomymized the genus. The species of the taxon exhibit variation in color and often sexual dimorphism. It is one of the most collected Argidae genera in the Neotropics and little is known about their habits and host plants. Scobina can be easily diagnosed by the presence of a preapical spine on the mid- and hindtibiae, presence of carinae on the head, presence of a genal carina, lack of a pronotal groove, closed radial cell of the hindwing, simple antennal flagellum of the male, and the pincer-like female sheath (Smith, 1992).

In this paper we report the first record of Scobina poeciloides (Ashmead, 1895) for Brazil and also update the geographic distribution of Scobina melanocephala (Lepeletier, 1823) and Scobina thoracica (Jorgensen 1913) 
for the state of Rio Grande do Sul. Scobina melanopyga (Klug, 1834) and Scobina torquata (Konow, 1903) already recorded for the state were also found in the study.

\section{Material and Methods}

Scobina specimens were identified among the sawflies collected between the years of 2008 e 2012 in tobacco (Nicotiana tabacum L.) fields of Santa Cruz do Sul (29047'41.2"S; 52 24'49.7'W) and Passa Sete (29 27'56.5”'s; $52^{\circ} 57^{\prime} 43.3^{\prime \prime} \mathrm{W}$ ) (both in state of Rio Grande do Sul) utilizing Malaise traps for entomofauna studies associated to the culture in southern Brazil. The identification of the species was done consulting Smith (1992), as well the diagnosis and geographic distribution. Collected material is deposited at the Entomological Collection of Santa Cruz (CESC), from the University of Santa Cruz do Sul.

Photographs of dorsal and lateral view of a representative of each species analyzed were made using a Canon EOS Rebel T3/1100D and enhanced using Adobe Photoshop CS5 software.

\section{Results}

78 specimens were identified of Scobina torquata, 30 of S. thoracica, 14 of S. melanopyga, 11 of S. melanocephala and three of S. poeciloides and, totalizing 136 sawflies.

\subsection{Scobina torquata (Konow, 1903) (Figure 1)}

Diagnosis: Head black. Mesonotum black with scutellum yellow orange; femora and tibiae yellow; apices of tibiae and entire tarsi black, bases of basitarsi may be whitish. Wings uniformly black; in forewing, vein $\mathrm{M}$ meets $\mathrm{Sc}+\mathrm{R}$ apical to $\mathrm{Sc}$; veins $\mathrm{M}$ and $\mathrm{Rs}+\mathrm{M}$ meet $\mathrm{Sc}+\mathrm{R}$ at nearly the same point; $\mathrm{Sc}$ of forewing perpendicular to $\mathrm{Sc}+\mathrm{R}$ and not parallel with vein $\mathrm{M}$; basal anal cell of forewing present (Smith, 1992).

Geographic distribution: Argentina: Misiones; Brazil: Rio Grande do Sul, Santa Catarina and São Paulo (Smith, 1992).

Material analyzed of CESC:

BRAZIL, Rio Grande do Sul: Passa Sete, Malaise, 14/I/2010, 2 ○ (CESC 31058/12); ${ }^{\lambda}$ (CESC 31048/05);

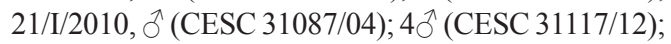
$5 \hat{\jmath}, 1$ 우 (CESC 31078/02); 2ㅅ, 1 우 (CESC 31108/04);

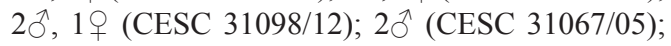
29/I/2010, ठै (CESC 31186/06); 7 ते (CESC 31174/04);

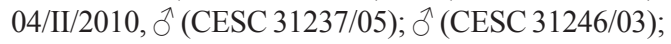
$\hat{\partial}(\operatorname{CESC} 31119 / 15) ; 12 / \mathrm{II} / 2010, \hat{\partial}(\mathrm{CESC} 31279 / 03) ; \hat{\jmath}$

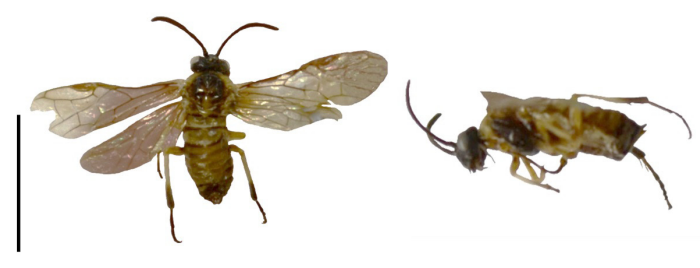

Figure 1. Dorsal and lateral view of Scobina torquata. Scale $0.5 \mathrm{~mm}$.
(CESC 31289/14); 18/II/2010, ठ̂ (31363/03; $2 \hat{\jmath}$ (CESC 31337/15); $\widehat{\partial}$ (CESC 31372/12); $3 \hat{\jmath}$ (CESC 31324/06); 13/III/2010, $2 \hat{\jmath}$ (CESC 31564/09); 13/III/2010, 今̂ (CESC 31581/06); 22/XII/2010, $20^{\uparrow}$ (CESC 30883/14); 23/

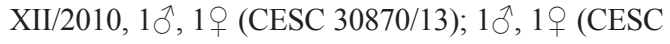
30859/15); Santa Cruz do Sul, Malaise, 01/I/2010, $\widehat{\delta}$ (CESC 32364/16); 10/I/2012, ㅇ (CESC 46595/6); 03/XI/2010, 4万, 2 ㅇ (CESC 36333/8); $2 \hat{\jmath}$ (CESC 36347/4); $2 \widehat{0}$ (CESC 36443/4); $\widehat{\partial}$ (CESC 36365/11);

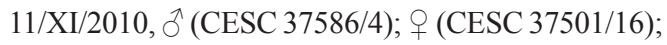
ㅇ (CESC 37380/10); ㅇ (CESC 37515/4); 13/XI/2010, ㅇ (CESC 37470/9); 19/XI/2010, ㅇ (CESC 37889/07); ㅇ (CESC 37866/02); 20/XI/2008, ô (CESC 15761/10);

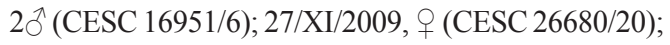
30/XI/2009, ठิ (CESC 26756/24).

\subsection{Scobina thoracica (Jorgensen, 1913) (Figure 2)}

Diagnosis: Head black. Thorax extensively yellow; femora yellow; tibiae black. Abdomen orange with apex black. Wings, including costa and stigma, black; basal anal cell present in forewing (Smith, 1992).

Geographic distribution: Argentina: Corrientes, Cordoba, Entre Rios, Formosa, Misiones, San Luis, Salta, Tucuman; Brazil: Rio Grande do Sul (first record), Santa Catarina; and Paraguay (Smith, 1992).

Material analyzed of CESC:

BRAZIL, Rio Grande do Sul: Passa Sete, Malaise, 06///2010, ô (CESC 30973/10); 14/I/2010, $2 \widehat{\bigcirc}$ (CESC 31048/05); $\hat{\partial}(\operatorname{CESC} 31005 / 04) ; 21 / \mathrm{I} / 2010$, q (CESC 31117/12); $\hat{\jmath}(\mathrm{CESC} 31078 / 02) ; 04 / \mathrm{II} / 2010, \hat{\jmath}$ (CESC 31228/06);

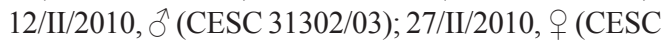
31451/04); 06/III/2010, क (CESC 31486/06); ठิ (CESC

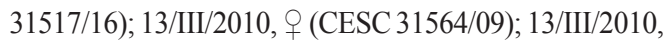
$\widehat{\jmath}$ (CESC 31539/08); 22/XII/2010, 令 (CESC 30883/14);

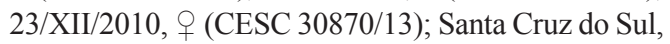
Malaise, 13/I/2009, ㅇ (CESC 21448/16); 28/I/2009, के (CESC 23095/07); 30/XI/2009, ô (CESC 26756/24); 14/XII/2009, o (CESC 30086/07); 18/XII/2009,

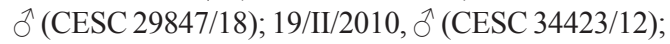
26/II/2010, $q$ (CESC 34615/09); 03/XI/2010, ô (CESC 36333/08); ㅇ (CESC 36380/03); 우 (CESC 36365/11); ऽิ (CESC 36456/14); 19/XI/2010, ô (CESC 37716/02); ㅇ (CESC 39639/7); 24/XII/2010, ㅇ (CESC 39545/04);

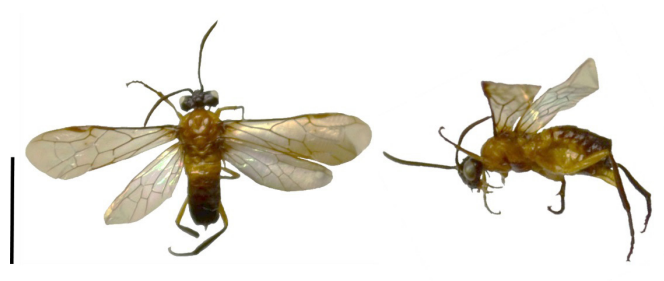

Figure 2. Dorsal and lateral view of Scobina thoracica. Scale $0.5 \mathrm{~mm}$. 
31/XII/2010,, (CESC 39746/02); 21/I/2011,, (CESC 40424/11).

\subsection{Scobina melanopyga (Klug, 1834) (Figure 3)}

Diagnosis: Head black. Mesepisternum and mesosternum orange; femora orange; extreme apex of hindfemur commonly blackish; tibiae and tarsii black. Abdomen orange with apex black. Wings, including costa and stigma, black; basal anal cell absent in forewing (Smith, 1992).

Geographic distribution: Argentina: Entre Rios, Formosa, Misiones; Brazil: Paraná, Rio de Janeiro, Rio Grande do Sul, Santa Catarina, São Paulo); and Paraguay (Smith, 1992).

Material analyzed of CESC:

Brazil, Rio Grande do Sul: Passa Sete, Malaise, 29/I/2010, o (CESC 31128/15); 04/II/2010, ㅇ (CESC 31237/05); 12/II/2010, ㅇ (CESC 31279/03); ㅇ (CESC 31302/03); 오 (CESC 31914/04); 우 (CESC 31289/14); 06/III/2010, 우 (CESC 31486/06); 13/III/2010, ㅇ (CESC 31564/09); ㅇ (CESC 31539/08); Santa Cruz do Sul, Malaise, 03/XI/2010, 2 + (CESC 36347/4); ㅇ (CESC 36257/06); 21/XII/2009,, (CESC 31735/19); 30/XI/2009, + (CESC 26756/24).

\subsection{Scobina melanocephala (Lepeletier, 1823) (Figure 4)}

Diagnosis: Head black; face below antennae white. Thorax with pleura and sterna Orange; femora and tibia yellow, except hindtibia which is black; tarsos black. Wings usually uniformly black (wings of female mostly blackish varying to yellowish withapex black and male with wings blackish or somewhat hyaline with blackish apex) (Smith, 1992).

Geographic distribution: Argentina: Salta; Bolivia; Brazil: Mato Grosso do Sul, Minas Gerais, Pará, Rio Grande do Sul (first record); Colombia; Ecuador; French Guiana; Guyana; Peru; Surinam; and Venezuela (Smith, 1992).

Material analyzed of CESC:

BRAZIL, Rio Grande do Sul: Passa Sete, Malaise, 12/II/2010, ㅇ (CESC 31302/03); ㅇ (CESC 31914/04); Santa Cruz do Sul, Malaise, 11/XII/2009, $q$ (CESC

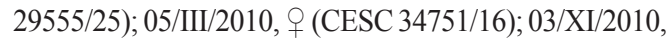
우 (CESC 36333/8); 우 (CESC 36280/11); 19/XI/2010,

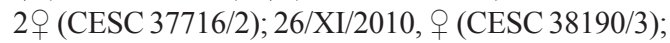
10/XII/2010, ㅇ (CESC 38929/3); 24/XII/2010, 우 (CESC 39479/03).

\subsection{Scobina poeciloides (Ashmead, 1895) (Figure 5)}

Diagnosis: Head black. Mesepisternum and mesosternum black; mesonotum usually mostly black; femora yellow; mid and hindtibia black, frontibia yellow. Wings uniformly infuscated black (Smith, 1992).

Geographic distribution: Brazil (first record): Rio Grande do Sul; and Mexico: Baja California Sur, Chiapas, Chihuahua, Colima, Durango, Jalisco, Nayarit, San Luis Potosi, Sinaloa, Tabasco, Veracruz, Yucatan (Smith, 1992).

Material analyzed of CESC:

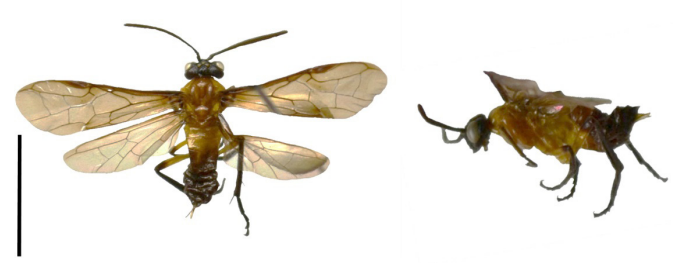

Figure 3. Dorsal and lateral view of Scobina melanopyga. Scale $0.5 \mathrm{~mm}$.

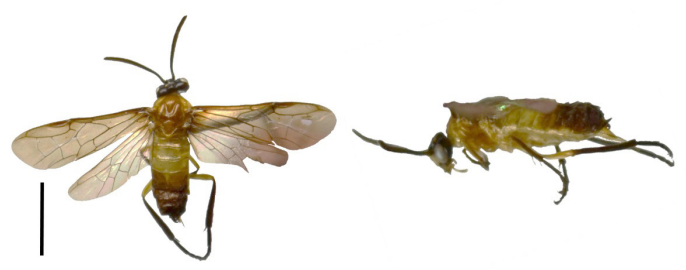

Figure 4. Dorsal and lateral view of Scobina melanocephala. Scale $0.5 \mathrm{~mm}$.

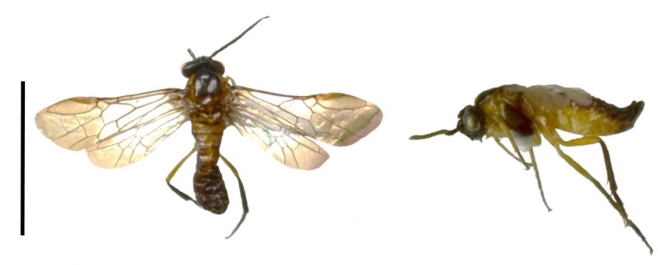

Figure 5. Dorsal and lateral view of Scobina poeciloides. Scale $0.5 \mathrm{~mm}$.

BRAZIL, Rio Grande do Sul: Passa Sete, Malaise, 04/II/2010, ô (CESC 31119/15); Santa Cruz do Sul, Malaise, 03/XI/2010, ๆ (CESC 36347/4); 19/XI/2010, ô (CESC 37703/17).

\section{References}

DALLA TORRE, C.G., 1894. Catalogus Hymenoptorum: Tenthredinidae incl. Uroceridae (Phyllophaga \& Xylophaga). Lipsiae: Sumptibus Guilelmi Engelmann. vol. 1, 459 p.

FERNÁNDEZ, F. and SHARKEY, M.J., editors, 2006. Introducción a los Hymenoptera de la Región Neotropical. Bogotá: Sociedad Colombiana de Entomología/Universidad Nacional de Colombia. $894 \mathrm{p}$.

HANSON, P.E. and GAULD, I.D., 1995. The Hymenoptera of Costa Rica. London: The Natural History Museum.

KONOW, F.W., 1907. Systematische Zusammenstellung der bisher bekannt geworden Chalastogastra. Zeitsehrift für Systematische Hymenopterologie Dipterologie, vol. 7, no. 5, pp. 177-496.

MALAISE, R., 1937. Old and new genera of Arginae (Hymen. Tenthred.). Entomologisk Tidskrift, vol. 58, pp. 47-59.

SMITH, D.R.A., 1992. Synopsis of the Sawflies (Hymenoptera: Symphtyta) of America South of the United States: Argidae. Memoirs of the American Entomological Society, no. 39, pp. 1-201. 